\title{
DETERMINASI DIRI MAHASISWA JURUSAN BIMBINGAN DAN KONSELING UNIVERSITAS NEGERI JAKARTA TAHUN ANGKATAN 2009-2013
}

\author{
Irma Ayuning Tyas ${ }^{1}$ \\ Gantina Komalasari ${ }^{2}$ \\ Eka Wahyuni ${ }^{3}$
}

\begin{abstract}
Abstrak
Artikel ini bertujuan untuk memaparkan hasil penelitian tentang determinasi diri mahasiswa jurusan Bimbingan dan Konseling Universitas Negeri Jakarta tahun angkatan 2009-2013. Penelitian dilaksanakan di jurusan Bimbingan dan Konseling Universitas Negeri Jakarta dengan populasi sebanyak 378 mahasiswa. Pengambilan sampel dilakukan dengan teknik Proportional Random Sampling. Peneliti menggunakan 76 mahasiswa sebagai sampel penelitian atau $20 \%$ dari masing-masing jumlah populasi per angkatan. Penelitian ini menggunakan metode penelitian survey. Instrumen yang digunakan pada penelitian ini yaitu kuesioner tentang determinasi diri yang merujuk pada teori Wehmeyer (1997). Setelah dilakukan uji coba, didapatkan hasil 55 item valid dan uji reliabilitas menggunakan koefisien Alpha Cronbach dengan nilai 0.753 yang berarti masuk dalam kategori tinggi dan layak untuk dijadikan alat ukur. Hasil penelitian menunjukan bahwa tingkat determinasi diri mahasiswa BK UNJ berada pada kategori sedang 47.37\%, rendah $28.95 \%$, dan tinggi $23.68 \%$.Persentase tertinggi berada pada kategori sedang yang artinya mahasiswa cukup mampu untuk membuat pilihan, membuat keputusan, mengatasi masalah, menetapkan tujuan dan pencapaian, mengobservasi diri, ketrampilan mengevaluasi diri, ketrampilan memberi penguatan diri, cukup memiliki lokus kontrol atau pusat kendali internal, cukup memiliki pengaruh positif dari efikasi dan harapan, cukup memiliki kesadaran diri, dan cukup memiliki pengetahuan diri.
\end{abstract}

Kata Kunci : Determinasi Diri

\section{Pendahuluan}

Peserta didik perguruan tinggi atau mahasiswa merupakan peserta didik yang berada pada jenjang tertinggi. Dengan berada pada jenjang yang paling tinggi, banyak masyarakat yang menaruh harapan terhadap mahasiswa dengan intelektualitas yang dimiliki oleh mahasiswa untuk membawa keadaan Indonesia kedalam keadaan yang lebih baik. Karena dari mahasiswalah akan tercipta calon-calon profesional dari berbagai bidang dan jurusannya masingmasing. Sebagai jenjang peserta didik yang paling tinggi, mahasiswa juga memiliki beberapa peranan penting, diantaranya adalah peran moral, peran sosial, dan peran intelektual. Untuk dapat memenuhi peranannya tersebut, mahasiswa juga harus memiliki kemandirian, asertifitas, keaktifan dan keterbu-

\footnotetext{
Mahasiswa Jurusan Bimbingan dan Konseling FIP UNJ, irmaayuningtyas@gmail.com

2 Dosen Bimbingan dan Konseling FIP UNJ, gantina_komalasari@yahoo.com

3 Dosen Bimbingan dan Konseling FIP UNJ, wahyuni.eka@gmail.com
} 
kaan (Fajar, 2000).

Dengan beberapa hal yang harus dimiliki oleh mahasiswa dalam mengoptimalkan prestasinya serta peranannya dalam kehidupan berbangsa dan bernegara, mahasiswa penting untuk memiliki determinasi diri yang bertindak sesuai dengan pilihannya sendiri. Hal ini sesuai dengan pernyataan Aristoteles yang menyatakan bahwa aspek terpenting dari remaja adalah kemampuan untuk memilih, dan bahwa determinasi diri merupakan jalan menuju kematangan (Santrock, 2007). Wehmeyer mendefinisikan determinasi diri sebagai perilaku dasar mengacu pada sikap dan kemampuan yang diperlukan untuk bertindak sebagai agen penyebab utama dalam kehidupan seseorang dalam membuat pilihan dan mengambil keputusan tanpa pengaruh dan tekanan dari pihak lain. Selain itu, Wehmeyer juga menambahkan bahwa tindakan seseorang adalah ditentukan diri jika orang yang bertindak secara mandiri, mengatur tingkah lakunya sendiri, memprakarsai dan menanggapi peristiwa dengan cara yang menunjukkan pemberdayaan psikologis, dan berperilaku dengan cara mewujudkan diri. Artinya, orang bertindak dengan cara yang positif menggunakan pengetahuan dan pemahaman mengenai karakteristik sendiri, kekuatan, dan keterbatasan (Agran, 1997).

Penelitian Benware dan Deci menunjukan hasil yang sama saat ditunjukan untuk mahasiswa, mahasiswa yang mempelajari materi teks dalam rangka benar-benar untuk dimanfaatkannya, biasanya cenderung memiliki motivasi instrinsik atau determinasi diri yang lebih dan memiliki pemahaman konseptual yang lebih baik dibandingkan dengan mereka yang belajar dengan tujuan agar dapat mengerjakan soal ujian. Oleh karena itu, orang yang memiliki prestasi belajar yang tinggi dapat dipastikan memiliki determinasi diri yang tinggi (Mitaugh, 2003).

Namun, berdasarkan pengamatan peneliti, masih banyak mahasiswa yang dalam kegiatan berkuliah, mereka melakukan sesuatu atas dasar kewajiban saja, dan hanya menuruti perintah dari dosen. Banyak dari mereka yang dalam kegiatan berkuliah sangat tergantung oleh pengaruh dari luar dirinya. Mereka sangat takut terhadap ancaman hukuman dan mengharapkan penghargaan ekstrinsik, dan cenderung memenuhi perintah. Mereka tidak termotivasi secara instrinsik, dan tidak menunjukkan mi- nat yang tinggi, namun mereka cenderung bertingkah laku dan berusaha untuk mengerjakan tugasnya agar dapat memperoleh penghargaan eksternal dan juga menghindari hukuman. Dalam hal ini, kontrol bersifat eksternal dan berarti tidak ada determinasi diri dalam diri mahasiswa (Schunk, 2002).

Hal ini juga terjadi pada mahasiswa jurusan Bimbingan dan Konseling. Hal ini telah dibuktikan oleh peneliti yang telah mewawancarai 10 mahasiswa BK UNJ yang berasal dari berbagai angkatan secara acak. Hasil dari wawancara yang telah dilakukan pada hari jum'at tanggal 06 september 2013 di lingkungan jurusan BK UNJ menyatakan bahwa sebagian besar dari mereka akan membaca buku dan mencari informasi mengenai materi kuliah di internet jika ada tugas dari dosen saja. Selain itu, sebagian besar dari mereka juga menyatakan bahwa alasan mereka mengerjakan tugas adalah agar mendapatkan nilai dan IP yang bagus, bukan karena adanya kebutuhan di dalam diri mereka.

Berdasarkan paparan sebelumnya, peneliti akan meneliti determinasi diri mahasiswa BK Universitas Negeri Jakarta mulai dari angkatan 2009 sampai dengan 2013.

\section{Kajian Teori \\ Determinasi Diri}

Determinasi diri adalah ketika seseorang dapat menentukan tindakan seseorang secara mandiri, mengatur tingkah lakunya sendiri, memprakarsai dan menanggapi peristiwa dengan cara yang menunjukkan pemberdayaan psikologis, dan berperilaku dengan cara mewujudkan diri (Agran, 1997). Determinasi diri adalah suatu sikap di mana seseorang atau individu dapat melakukan sesuatu atas kehendaknya sendiri bukan karena tekanan dari pihak lain. Sehingga seseorang dalam melakukan tindakan memang karena menyadari bahwa ia perlu melakukan hal tersebut.

\section{Elemen Komponen perilaku Determinasi Diri}

Wehmeyer dalam Agran mengidentifikasi 11 elemen komponen yang berhubungan dengan perilaku determinasi diri (Agran, 1997). Komponen tersebut yaitu: 


\section{Membuat pilihan}

Guess dalam Agran mengajukan tiga level dalam membuat pilihan, yaitu pilihan sebagai pengindikasi preferensi, pilihan sebagai proses membuat keputusan, serta pilihan sebagai ekspresi atas kemandirian dan martabat. Reid, dkk. dalam Agran mengidentifikasi dua komponen dasar dalam instruksi membuat pilihan, yang pertama yaitu melibatkan perilaku tertentu yang diperlukan untuk memilih satu hal atau peristiwa dari dua atau beberapa alternatif. Yang kedua yaitu mengarahkan tindakan tersebut menuju pemilihan dari hasil pilihannya tersebut.

\section{Membuat keputusan}

Terdapat kemiripan antara membuat pilihan dan membuat keputusan. Membuat pilihan mengacu pada proses pemilihan alternatif berdasarkan pada pilihan individual. Membuat keputusan mengacu pada satu set keterampilan yang lebih luas yang menggabungkan pembuatan pilihan sebagai salah satu dari sekian banyak komponen yang ada.

\section{Memecahkan masalah}

Elemen ketiga adalah pemecahan masalah. Pemecahan masalah juga berkaitan dengan pengambilan keputusan, karena pengambilan keputusan merupakan sebuah proses di mana individu mempertimbangkan berbagai solusi atau pemecahan masalah. Masalah itu sendiri adalah merupakan sebuah tugas yang solusinya belum didapatkan, atau lebih khusus masalah adalah situasi tertentu di mana seseorang harus merespon agar dapat berfungsi secara optimal dan efektif dalam lingkungannya. Seperti halnya proses pembuatan pilihan, ketrampilan memecahkan masalah juga tertanam di hampir semua prosedur pembuatan keputusan. Proses membuat keputusan di-mulai dengan membuat daftar pilihan yang sudah diidentifikasi. Praktisnya, individu harus menggunakan pemecahan masalah sebelum terjadi-nya pembuatan keputusan. Dalam pemecahan masalah, penekanan instruksional biasanya meliputi tiga titik fokus yaitu identifikasi masalah, penjelasan masalah dan analisis, dan penyelesaian masalah.

\section{Penetapan tujuan dan pencapaian}

Untuk menjadi agen menyebab dalam kehidupan, individu perlu memiliki ketrampilan yang diper- lukan untuk merencanakan, mengatur, dan mencapai tujuan. Tujuan di sini mengandung beberapa makna, menurut Locke dan Latham tujuan di sini mencangkup arti penting dari istilah-istilah seperti niat atau maksud, tugas, batas waktu, tujuan, arahan, dan tujuan akhir. Semua ini memiliki kesamaan makna bahwa ada sesuatu yang ingin dicapai oleh seseorang.

\section{Kemampuan mengobservasi diri}

Menguji keadaan lingkungan belajar, dan mengevaluasi apa yang diinginkan.

\section{Kemampuan mengevaluasi diri}

Membandingkan tingkah laku belajar yang diawasi sendiri dengan tujuan yang dicapai.

\section{Kemampuan menguatkan diri}

Berperan aktif dalam belajar, membuat jadwal penguat baru untuk lebih memotivasi dirinya dalam belajar.

\section{Lokus kontrol internal}

Rotter dalam Agran mendefinisikan lokus kontrol sebagai sejauh mana seseorang merasakan hubungan yang berkelanjutan antara tindakannya dan hasil. Mercer dan Snell dalam Agran mendekripsikannya dengan cara berikut:

a. Jika individu memiliki lokus kontrol internal, ia melihat penguatan sebagai akibat paling utama dari setiap tindakannya.

b. Jika individu memiliki lokus kontrol eksternal, ia melihat penguatan sebagai hasil dari kekuatan dari luar, contohnya keberuntungan, nasib, kesempatan, dan lainnya.

Lokus kontrol internal telah dikaitkan dengan hasil adaptif, termasuk hasil pendidikan yang positif dan prestasi, serta meningkatkan waktu dan perhatian pada tugas sekolah yang terkait.

\section{Pengaruh positif dari efikasi dan harapan}

Efikasi diri mengacu pada keyakinan bahwa seseorang dapat berhasil melaksanakan perilaku yang diperlukan untuk memproduksi hasil yang diberikan. Efikasi harapan mengacu pada keyakinan individu bahwa jika suatu perilaku tertentu dilakukan, hal itu akan menyebabkan hasil yang diharapkan. Ini menjadi jelas bahwa kedua-nya perlu dimiliki oleh individu tetapi tidak cukup untuk menciptakan sebuah determinasi diri. Sederhananya, individu harus percaya bahwa mereka dapat melakukan perilaku tertentu yang 
diperlukan untuk mencapai hasil yang diinginkan, dan bahwa jika perilaku tersebut dilakukan, akan menghasilkan hasil yang diinginkan. Jika seorang individu tidak yakin bahwa mereka dapat melakukan perilaku tertentu, maka mereka tidak akan melakukan tindakan itu. Namun, seorang individu mungkin percaya bahwa mereka mampu melakukan perilaku tertentu, tetapi karena pengalaman masa lalu, mungkin tidak yakin bahwa hasil yang diinginkan akan benar-benar terwujud walaupun sudah melakukan perilaku yang dibutuhkan.

\section{Kesadaran diri}

Untuk bertindak dengan kesadaran diri, seseorang harus memiliki pemahaman dasar tentang kelebihan, kelemahan, kemampuan, dan keterbatasan serta pengetahuan tentang bagaimana memanfaatkannya agar memberikan keuntungan dan mempengaruhi kualitas hidup mereka. Pada dasarnya individu harus terlebih dahulu memiliki rasa pembentukan diri dan kesadaran mereka sebagai individu yang unik, individu harus menyadari keunikan dan perbedaan mereka dari orang lain dan harus memahami bahwa mereka memiliki keterbatasan dan akan bertahan meskipun keadaan akan berubah.

\section{Pengetahuan diri}

Pengetahuan diri biasanya muncul pada saat individu berusia dua tahun, pada saat itu anak perlu mengembangkan kesadaran diri dan pemahaman diri untuk mempelajari apa yang mereka lakukan dengan baik, bantuan apa yang mereka butuhkan, dimana letak minat mereka, dan bagaimana menggunakan bakat mereka untuk memberikan keuntungan bagi mereka sendiri.

\section{Metode Penelitian}

Metode yang digunakan dalam penelitian ini adalah survey dengan menggunakan studi deskriptif. Penelitian dilaksanakan selama tujuh bulan, dimulai sejak bulan Agustus 2013 sampai dengan bulan Maret 2014 yang dilakukan kepada mahasiswa Bimbingan dan Konseling Universitas Negeri Jakarta dengan jumlah populasi sebanyak 378 mahasiswa dan sampel $20 \%$ dari jumlah populasi yaitu sebanyak 76 yang diambil dengan mmenggunakan teknik proportional random sampling. Ada pun tempat penelitiannya adalah di lingkungan jurusan Bimbingan dan Konseling kampus Universitas Negeri Jakarta dengan cara memberikan kuesioner mengenai determinasi diri yang merujuk pada teori Wehmeyer (1997) kepada mahasiswa. Teknik analisis data yang digunakan pada penelitian ini yaitu teknik analisis data deskriptif, di mana hasil penelitian akan diinterpretasikan dari bentuk persentase menjadi gambaran deskriptif.

\section{Hasil dan Pembahasan}

Hasil penelitian secara keseluruhan menunjukkan bahwa mahasiswa BK memiliki determinasi diri yang sedang. Hal ini dilihat dari rerata skor responden sebesar 155 dan standar deviasi sebesar 13, jumlah responden yang termasuk ke dalam kategori tinggi adalah sebanyak 18 orang atau $18,67 \%$ dan kategori sedang menempati jumlah tertinggi sebanyak 36 orang $47,37 \%$, sedangkan responden yang termasuk ke dalam kategori rendah yaitu sebanyak 22 orang atau $28,95 \%$. Untuk lebih jelasnya akan digambarkan pada grafik berikut ini:

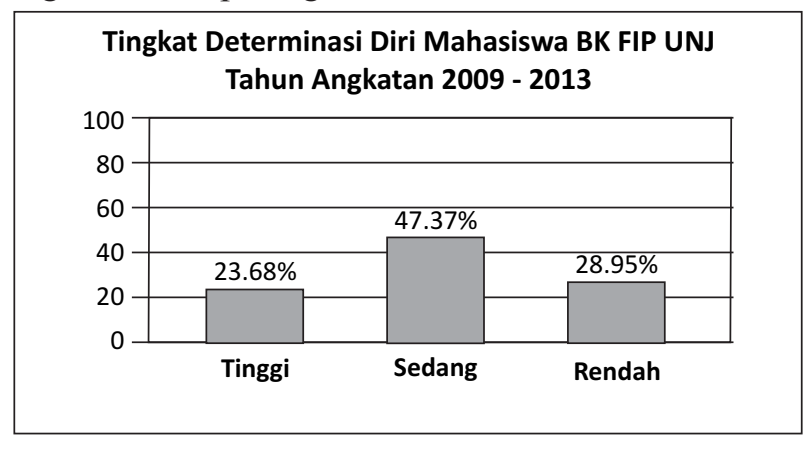

Grafik Tingkat Determinasi Diri Mahasiswa BK FIP UNJ Tahun Angkatan 2009-2013

Mahasiswa yang memiliki determinasi diri yang baik, memiliki kapasitas untuk mengesampingkan intervensi dari pihak luar sehingga mereka dapat bertindak berdasarkan keinginan mereka sendiri (Michael, 2007). Orang yang memiliki determinasi tinggi merupakan orang yang bertindak secara mandiri, mampu mengatur perilakunya sendiri, memulai dan merespon kejadian dengan sikap yang dikuasai secara psikologis, serta bertindak dengan sikap sadar diri (Agran, 1997).

Pada hasil penelitian ini, mahasiswa yang paling banyak memperoleh kategori rendah adalah 
mahasiswa yang berasal dari angkatan 2009 dengen persentase kategori rendah sebesar $61,54 \%$ dan jumlah frekuensi sebanyak delapan orang mahasiswa. Delapan orang mahasiswa ini, peneliti telah melakukan wawancara melalui media online pada tanggal 31 Mei 2014 mengenai penyebab rendahnya determinasi diri. Wawancara ini memberikan hasil bahwa tiga dari delapan mahasiswa menyatakan kemungkinan hal itu terjadi karena mereka sudah mulai merasa bosan dengan kegiatan yang ada di perkuliahan, jadi hal ini menyebabkan me-reka hanya akan melakukan sesuatu jika mendapatkan penghargaan saja. Lalu, dua dari delapan menyatakan hal ini terjadi karena mereka merasa bahwa hasil yang bagus lebih dihargai, sehingga mereka lebih memilih mendapatkan hasil yang bagus tanpa memperdulikan pemahaman yang lebih dari hal yang dipelajari. Sedangkan sisanya tiga orang mahasiswa menyatakan hal ini terjadi karena sudah ada kegiatan lain di luar kampus, merasa bahwa belajar yang sungguh-sungguh jika dibandingkan dengan belajar yang hanya jika disuruh oleh dosen maka hasil atau nilainya sama saja, dan merasa sudah terbiasa melakukan sesuatu jika disuruh saja sejak sebelum masuk kuliah, sehingga hal ini menyebabkan ia memiliki determinasi diri yang rendah.

Menurut Thoha, ada beberapa faktor yang mempengaruhi kemandirian dan determinasi diri pada seseorang. Faktor yang pertama adalah faktor dari dalam diri yaitu jenis kelamin, tingkat kecerdasan, dan kematangan usia (Thoha, 1996). Untuk faktor jenis kelamin, Hal ini telah dibuktikan oleh hasil penelitian yang telah dilakukan oleh peneliti bahwa persentase kategori rendah lebih banyak diperoleh oleh mahasiswa laki-laki dibandingkan dengan mahasiswa perempuan. Untuk mahasiswa laki-laki 41,70\% dinyatakan memiliki determinasi diri yang rendah, sedangkan mahaiswa perempuan hanya $26,60 \%$ yang dinyatakan rendah. Penelitian yang dilakukan oleh Safrial pada tahun 2007 juga menghasilkan hasil yang sama, yaitu mahasiswa laki-laki dalam hal motivasi, memperoleh persentase kategori tinggi sebesar 21\% sedangkan mahasiswa perempuan memperoleh $27 \%$.Selain itu, studi yang dilakukan oleh Newcastle University pada tahun 2013 menemukan bahwa pada dasarnya otak remaja perempuan memang matang lebih dini dibandingkan remaja laki-laki. Menurut Dr. Marcus Kai- ser dari Newcastel University, seiring dengan bertambahnya usia, bagian-bagian pada otak menjadi lebih kecil karena koneksi antarsel yang tidak perlu akan dipangkas. Hal ini menyebabkan bagian pengolah menjadi lebih ramping dan efisien, yang menyebabkan otak lebih mudah untuk berkonsentrasi atau fokus pada hal tertentu dan dalam hal ini otak perempuan sudah memulai pemangkasan sejak usia 10 tahun, sedangkan laki-laki pada usia 20 tahun. Hal ini secara tidak langsung menjawab pertanyaan mengapa remaja perempuan lebih cepat dewasa dan mandiri dibandingkan dengan remaja laki-laki.

Faktor selanjutnya yang mempengaruhi kemandirian atua determinasi diri adalah faktor keluarga. Dalam hal ini yang paling berpengaruh dalam keluarga adalah orangtua, sesuai dengan pernyataan Thoha bahwa pengaruh keluarga terhadap anak adalah meliputi aktivitas pendidikan dalam keluarga. Kecenderungan cara mendidik anak, cara memberi penilaian pada anak, bahkan sampai pada cara hidup orangtua berpengaruh terhadap kemandirian anak. Dalam hal ini, peneliti mendeskripsikan tingkat determinasi diri berdasarkan latar belakang tingkat pendidikan orangtua. Hasil penelitian menunjukan bahwa mahasiswa yang memiliki orangtua berpendidikan SMA atau di bawahnya, hanya memperoleh peresentase kategori tinggi sebesar 18,60\% dibandingkan dengan mahasiswa yang memiliki orangtua berpendidikan di atas D3 yaitu memperoleh persentase kategori tinggi lebih banyak yaitu sebesar 27,27 $\%$.

Perbedaan latar belakang pendidikan orangtua tentu juga berpengaruh terhadap cara pola asuh orangtua, menurut penelitian yang telah dilakukan oleh Retno pada tahun 2005 mengenai pengaruh pola asuh orangtua terhadap kemandirian siswa memberikan hasil bahwa meningkat atau menurunnya kemandirian siswa dalam belajar ditentukan oleh pola asuh orangtua sebesar $63,92 \%$ sedangkan sisanya $36,08 \%$ ditentukan oleh faktor lain yang juga berpengaruh terhadap kemandirian siswa dalam belajar. Hal ini juga dapat diartikan bahwa latar belakang pendidikan orangtua mempengaruhi bagaimana kemandirian atau determinasi diri pada mahasiswa.

Selain faktor keluarga, menurut Thoha sistem pendidikan juga dapat mempengaruhi kemandirian dan determinasi diri. Seperti halnya pada hasil pene- 
litian ini, bahwa mahasiswa yang berasal dari SMK lebih memiliki determinasi diri yang baik, dibandingkan dengan mahasiswa yang berasal dari SMA. Mahasiswa yang berasal dari SMK memperoleh persentase kategori tinggi sebesar $66,67 \%$, sedangkan mahasiswa yang berasal dari SMA hanya memperoleh persentase kategori tinggi sebesar 23,28\%. Menurut Thoha proses pendidikan di sekolah yang tidak mengembangkan demokrasi pendidikan dan cenderung menekankan indoktrinsasi tanpa argumentasi akan menghambat perkembangan kemandirian remaja sebagai siswa. Seperti yang telah diketahui bahwa perbedaan antara SMA dan SMK adalah bahwa SMK lebih banyak praktik. Fitmaurice dalam Nugraheni 2005 menyatakan bahwa praktek dalam belajar cenderung menekankan pada peran siswa secara langsung sehingga menumbuhkan kemandirian (Nugraheni, 2007). Secara tidak langsung jika hal ini berjalan dalam jangka waktu yang cukup lama, maka akan menumbuhkan kemandirian bagi siswanya.

Gambaran tingkat determinasi diri mahasiswa dapat terlihat dari deskripsi tiap aspek. Dari kesebelas aspek, semua persentase terbesar berada pada kategori sedang, hal ini berarti bahwa mahasiswa Bimbingan dan Konseling Universitas Negeri Jakarta tahun angkatan 2009-2013 sudah cukup mampu untuk membuat pilihan, membuat keputusan, mengatasi masalah, menetapkan tujuan dan pencapaian, cukup memiliki kemampuan mengobservasi diri, ketrampilan mengevaluasi diri, keterampilan memberi penguatan diri, cukup memiliki lokus kontrol atau pusat kendali internal, cukup memiliki pengaruh positif dari efikasi dan harapan, cukup memiliki kesadaran diri, dan cukup memiliki pengetahuan diri.

\section{Kesimpulan dan Saran}

Hasil penelitian menunjukan gambaran mengenai determinasi diri pada mahasiswa BK UNJ yaitu bahwa mahasiswa BK UNJ angkatan 2009 sampai dengan 2013 yang memiliki determinasi diri dengan kategori tinggi adalah $23,68 \%$ dan tingkat determinasi diri dengan kategori sedang sebanyak $47,37 \%$, sedangkan mahasiswa yang memiliki tingkat determinasi diri dengan kategori rendah sebanyak $28,95 \%$.
Berikut adalah saran-saran yang dapat diajukan kepada pihak-pihak yang terkait:

1. Mahasiswa jurusan bimbingan dan konseling FIP UNJ, agar lebih menyadari tingkat determinasi diri yang mereka miliki serta berusaha meningkatkan determinasi dirinya dengan cara munculkan niat atau kesadaran dalam diri dalam belajar, memulai belajar tanpa disuruh dosen, membaca buku materi walaupun tidak ada tugas, jangan terlalu berfokus pada nilai atau imbalan, belajar dengan mandiri, buatlah catatan tentang kegiatan-kegiatan yang harus dilakukan.

2. Untuk pihak dari jurusan Bimbingan dan Konseling Universitas Negeri Jakarta disarankan untuk memperhatikan keadaan determinasi diri mahasiswa dengan cara menambahkan materi determinasi diri pada program MPA ( Masa pengenalan Akademik) dan program bimbingan untuk dosen PA (Pembimbing Akademik).

3. Untuk peneliti selanjutnya, yang ingin meneliti mengenai determinasi diri, disarankan untuk menghubungkan variabel lain yang berpengaruh misalnya, kecerdasan, pola asuh orangtua, asal daerah, jenis kelamin, prestasi, latar belakang pendidikan dll, agar semakin banyak data dan pengetahuan mengenai determinasi diri. Serta bagi peneliti selanjutnya, yang ingin meneliti mengenai determinasi diri disarankan untuk memperhatikan aspek psikologis dari responden, dengan cara menanyakan kesiapan, menjelaskan asas kerahasiaan, dan manfaat penelitian, agar penelitian mendapatkan hasil yang akurat. 


\section{Daftar Pustaka}

Agran, Martin. (1997). Student Directed Learning : Teaching self-Determination Skills. United States: Cole Publishing Company .

Deci, L. E. \& Ryan, R. M. (2002). Handbook of self-determination research.

NewYork; University Rochester

Deci, E.L, \& Ryan, R. M. (2012). Self-determinationtheory in health care and its relations to motivational interviewing:a few comment. International Journal of Behavioral Nutrition and Phsycal Activity.
Deci, E. L., \& Ryan, R. M. (2000). The 'what' and 'why' of goal pursuits: Human needs and the self-determination of behavior. Psychological Inquiry, 11, 227-268.

Mithaug, Agran, Martin, Wehmeyer.( 2003) .Self-Determied Learning Theory, New Jersey: Lawrence Erlbaum Associates.

Schunk, D.H., Pintrich, P. R., \& Meece, J.L .(2002). Motivation in Education. Upper Saddle River, New Jersey. Pearson Education.

Wehmeyer, Michael L (2003). Self-Determined Learning Theory. London: Lawrence Erlbaum Associates. 